\title{
Seropositivity to Leptospira interrogans in a herd of vicuñas (Vicugna vicugna) under captivity in northern Chile
}

\author{
Cecilia Norambuena ${ }^{\mathrm{a}, \mathrm{b}^{*}}$, Mariana Roldán ${ }^{\mathrm{a}}$, Christian Tuemmers ${ }^{\mathrm{a}}$, \\ Gerardo Quezada $^{\mathrm{a}}$, Oriana Betancourt ${ }^{\mathrm{a}}$
}

\begin{abstract}
Twenty-one vicuñas (Vicugna vicugna) from a Chilean breeding unit were tested to serovars Pomona, Canicola, Copenhageni, Ballum and Grippotyphosa of Leptospira interrogans using the microscopic microagglutination technique. The results showed that $23.8 \%$ of the samples reacted to the serovar Grippotyphosa which has been related to abortions in South American camelids. Key words: leptospirosis, camelidae, Vicugna vicugna.
\end{abstract}

The vicuña (Vicugna vicugna) is a wild herbivorous mammal of the Camelidae family that inhabits the Andean peatlands called "bofedales" of the biogeographic provinces of the Puna and Altoandina of Chile, Bolivia, Peru, and Argentina. In Chile, ninety-five percent of the vicuña population is located in the Arica and Parinacota Region, above 3,000 m.a.s.l. This vicuña population has shown a progressive decrease from 25,000 individuals in 1990 to 12,061 in $2018^{1}$.

Domestic South American camelids show low fertility in altiplanic conditions, close to $50 \%$ of pregnancy rate (Fernandez-Baca 1991). Vicuñas have shown pregnancy rates of 59.7\% in the Lauca National Park (Urquieta and Rojas 1990) and 64\% in a captive breeding unit (Raggi and Parraguez 2005). There have been reports of embryonic and fetal mortality in domestic camelids (Fernandez-Baca et al 1970) and vicuñas (Ellmen 2004) in the High Andes, as well as in well-nourished alpacas in New Zealand which had been imported from Chile (Knight et al 1995). The low nutritional level, high consanguinity of herds, traumatic events, congenital and acquired disorders of the reproductive tract, and infectious diseases could be the reason for the low reproductive performance in camelids (Rodríguez et al 2014, Pearson et al 2014). Among the infectious etiologies, Leptospirosis caused by spirochetes of the Leptospira genus, is one of the most important causes for low reproductive performance in North American camelids (Tibary et al 2006). The objective of the study was to determine the seropositivity of Leptospira spp. in a herd of vicuñas under captivity in the Chilean High Andes.

Received: 17.05.2019.

Accepted: 11.10.2019.

aDepartamento de Medicina Veterinaria, Facultad de Recursos Naturales, Universidad Católica de Temuco, Temuco, Chile.

bNucleo de Investigación en Producción Alimentaria, Facultad de Recursos Naturales, Universidad Católica de Temuco, Temuco, Chile.

*Corresponding author: C Norambuena; Manuel Montt 056, Temuco, PC 4780000, Chile; mcnorambuena@uct.cl

1 Shaw et al 2012, CONAF, pers. commun.
The study was carried out in the Vicuña Breeding Unit of Limani ( $18^{\circ} 23^{\prime} \mathrm{S}, 69^{\circ} 34^{\prime} \mathrm{W}$; 4,385 m.a.s.l.) located in the Arica and Parinacota Region, Chile. The sampling was authorised by the Agriculture and Livestock Service of Chile (SAG). The unit has 49 vicuñas (13 males, 21 females, and 15 young vicuñas under one year of age) in a $40 \mathrm{Ha}$ of bofedal. A temporary capture of 21 pregnant and non-pregnant adults from 2 to 6 years old, was carried out. Each female was tied up in sternal decubitus position without sedation, and $4 \mathrm{ml}$ of blood was obtained by jugular puncture using a syringe and then collected in heparine tubes. The samples were centrifuged at $1,500 \mathrm{rpm}$ for $15 \mathrm{~min}$, and plasma was transported to Universidad Católica de Temuco by air, and stored at $-80{ }^{\circ} \mathrm{C}$ until analysis.

The antibody reaction against the serovars Pomona, Canicola, Copenhageni, Ballum, and Grippotyphosa of Leptospira interrogans was determined using the microscopic microagglutination technique, in the laboratory of Veterinary Microbiology, Universidad de Concepción. The antigenic strains and positive controls were provided by SAG. Plasma samples were examined at dilutions of 1:100, 1:200, 1:400, 1:600, 1:1,800 and incubated with the antigen at $37{ }^{\circ} \mathrm{C}$ during 2 hours. Sera with $\geq 50 \%$ agglutination or more was considered positive, with titers equal to or greater than the 1:100 dilution.

Five (23.8\%) out of 21 vicuñas analysed were reacted positively to the serovar Grippotyphosa of $L$. interrogans with a titer $(1: 100)$ that ruled out active infection. The results of previous studies of seropositivity to $L$. interrogans in vicuñas are diverse. In Argentina, between 7\% and $62 \%$ out of 73 vicuñas from wild and captive herds, reacted to the serovars Copenhageni and Castelloni, and the study did not include the serovar Grippotypposa (Llorente et al 2002). In Peru, 77.4\% out of 195 vicuñas from wild and captive herds were positive to the serovars Icterohaemorrhagiae and Pomona in the Huancavelica and Ayacucho Region (Rosadio et al 2015). On the other hand, in south Puno, only $1.9 \%$ (4/207) of the vicuñas were positive to the serovars Pomona, Autumnalis, Bratislava, and Copenhageni, including Grippotyphosa (Risco-Castillo et al 2014) screened against 17 serovars. 
The seropositivity of the serovars Pomona (33\%), Hardjo (14\%), Copenhageni (11\%), and Grippotyphosa (8\%) has been registered in clinically healthy vicuñas of the captivity Breeding Unit of Cculicculine, Chile. The Units of Ankara and Limani were negative, although the sample size of the latter Unit was small (8 animals) (SAG 2002, Perez et al 2007). Based on the results of the present study, it is possible that leptospirosis could potentially affect the fertility of vicuñas in the Chilean highlands considering that serovars Pomona and Grippotyphosa were associated with episodes of abortions in North American camelids (Lohr et al 2007, Fowler 2010). However, the finding of serological reactivity is not enough to state that infertility of the herd can be attributed to pathogenic Leptospira sp. infection. It is recommended to study the prevalence of this disease in wild herds and epidemiological surveillance of the captive systems to prevent the spread of this disease. The identification of the wild species that could act as a reservoir of the causative serovars for humans and domestic species would also be helpful to have an action plan for the control of the disease. In conclusion, $23.8 \%(5 / 21)$ of the vicuñas under captivity in Limani were positive to the serovar Grippotyphosa of Leptospira interrogans.

\section{REFERENCES}

Ellmen E. 2004. Efecto de la suplementación alimentaria estratégica sobre la eficiencia reproductiva en vicuñas mantenidas en semicautiverio. Memoria de Título, Universidad de Chile, Santiago, Chile.

Fernández-Baca S. 1991. Avances y perspectivas del conocimiento de los camélidos sudamericanos. FAO, Santiago, Chile.

Fernandez-Baca S, W Hansel, Novoa C. 1979. Embryonic mortalitity in the alpaca. Biol Reprod 3, 243-251.

Fowler M, Bravo PW. 2010. Infectious diseases. In: Fowler M (ed). Medicine and Surgery of Camelids. $3^{\text {rd }}$ ed. Willey-Blackwell Inc, Iowa, USA, Pp 173-230.

Knight TW, Ridland M, Scott I, Death AF, Wyeth TK. 1995. Foetal mortality at different stages of gestation in alpacas (Lama pacos) and the associated changes in progesterone concentrations. Anim Reprod Sci 40, 89-97.

Lohr CV, Bildfell RJ, Heidel JR, Valentine BA, Schaefer DL. 2007. Abortion in llamas and alpacas: a 5 year retrospective study. Vet Pathol 44, 5.

Llorente P, Leoni L, Martínez Vivot M. 2002. Leptospirosis en camélidos sudamericanos. Estudio de prevalencia serológica en distintas regiones de la Argentina. Arch Med Vet 34, 59-68.

Pearson L, Rodriguez J, Tibary A. 2014. Disorders and diseases of pregnancy. In: Cebra C, Anderson DE, Tibary A, Van Saun RJ, Johnson LW (eds). Llama and alpaca care: medicine, surgery, reproduction, nutrition, and herd health. Elsevier Inc., Philadelphia, USA, Pp 256-273.

Pérez C, Arredondo F, Turra L. 2007. Manejo sanitario de la vicuña. Boletín Veterinario Oficial $N^{\circ} 9$, Servicio Agrícola y Ganadero, Chile.

Raggi LA, Parraguez VH. 2005. Manejo reproductivo de la vicuña. In: Galaz J, González G (eds). Técnicas de Manejo Productivo de la Vicuña (Vicugna vicugna, Molina, 1782) en Chile. Corporación Nacional Forestal y Fundación para la Innovación, Santiago, Chile, Pp 209-221.

Risco-Castillo V, Wheeler J, Rosadio R, García-Pena F, Arnaiz-Seco I, et al. 2014. Health impact evaluation of alternative management systems in vicuña (Vicugna vicugna mensalis) populations in Perú. Trop Anim Health Prod 46, 641-646.

Rodríguez J, Pearson L, Tibary A. 2014. Infertility and subfertility in the female camelid. In: Cebra C, Anderson DE, Tibary A, Van Saun RJ, Johnson LW (eds). Llama and alpaca care: medicine, surgery, reproduction, nutrition, and herd health. Elsevier Inc., Philadelphia, USA, Pp 216-242.

Rosadio R, Véliz A, Castillo H, Yaya K, Rodríguez A, Rivera H, Wheeler J. 2015. Seroprevalence to pathogenic leptospira in Peruvian alpacas and vicuñas. Small Rumin Res 130, 256-259.

SAG. 2002. Oficio Ordinario No 1251 del 14 de Agosto del 2002. Resultados exámenes serológicos y parasitarios en vicuñas silvestres y en cautiverio.

Shaw AK, Galaz JL, Marquet P. 2012. Population dynamics of the vicuña (Vicugna vicugna): density dependence, rainfall, and spatial distribution. J Mammal 93, 658-666.

Tibary A, Fite C, Anouassi A, Sghiri A. 2006. Infectious causes of reproductive loss in camelids. Theriogenology 66, 633-647.

Urquieta B, Rojas R. 1990. Studies on the reproductive physiology of the vicuña (Vicugna vicugna). In: Russell B, Jane M, John I (eds). Livestock reproduction in Latin America. International Atomic Energy Agency, Viena, Austria, Pp 407-428. 